\title{
Meanings of Family Support in the Treatment of Drug Dependence ${ }^{1}$
}

\author{
Laís Ramos Sanches², Tassiana Gonçalves Constantino dos Santos², \\ Thaísa Borges Gomes ${ }^{2}$, Marcelo Dalla Vecchia ${ }^{2}$ \\ ${ }^{2}$ Universidade Federal de São João del-Rei, São João del-Rei-MG, Brazil
}

\begin{abstract}
The family is a key element of social support in the treatment of people who experience problems resulting from the use of alcohol and other drugs. This article aimed to understand the meanings of individuals under treatment due to the problematic use of alcohol and other drugs in relation to family participation. Six semi-structured interviews were carried out with people who adhered or not to the treatment proposed by an institution similar to a therapeutic community, analyzed later by analysis of thematic content. It was possible to observe (a) the low family involvement during the treatment, (b) the stigmatization and the individualization of the problematic use of alcohol and other drugs, and (c) the care focused on the figure of women. Guidance, listening and support needs for family members need to be properly examined during treatment to promote adherence.
\end{abstract}

Keywords: drug (abuse), family, treatment, social networks

\section{Significados do Apoio Familiar no Tratamento da Dependência de Drogas}

Resumo: A família é um elemento fundamental do apoio social no tratamento de pessoas que vivem problemas decorrentes do uso de álcool e outras drogas. Este artigo objetivou compreender os significados constituídos por indivíduos em tratamento devido ao uso problemático de álcool e outras drogas com relação à participação da família. Foram realizadas seis entrevistas semi-estruturadas com pessoas que aderiram ou não ao tratamento proposto por uma entidade assemelhada a uma comunidade terapêutica, analisadas posteriormente por análise de conteúdo temática. Foi possível observar (a) o escasso envolvimento familiar durante o tratamento, (b) a estigmatização e a individualização do uso problemático de álcool e outras drogas, e (c) o cuidado focalizado na figura de mulheres. Necessidade de orientação, de escuta e de suporte aos familiares precisam ser devidamente examinadas no decorrer do tratamento a fim de favorecer a adesão.

Palavras-chave: droga (abuso), família, tratamento, redes sociais

\section{Significados del Apoyo Familiar en el Tratamiento de la Dependencia de Drogas}

Resumen: La familia es un elemento fundamental del apoyo social en el tratamiento de personas que viven problemas derivados del uso de alcohol y otras drogas. Este trabajo objetivó comprender los significados constituidos por individuos en tratamiento debido al uso problemático de alcohol y otras drogas con relación a la participación de la familia. Se realizaron seis entrevistas semiestructuradas con personas que se adhirieron o no al tratamiento propuesto por una entidad asimilada a una comunidad terapéutica, analizadas posteriormente por análisis de contenido temático. Se ha podido observar (a) la escasa participación familiar durante el tratamiento, (b) la estigmatización y la individualización del uso problemático de alcohol y otras drogas, y (c) el cuidado centrado en la figura de mujeres. Las necesidades de orientación, escucha y apoyo a los familiares deben ser debidamente examinadas durante el tratamiento para favorecer la adhesión.

Palabras clave: abuso de drogas, familia, terapia, redes sociales

The family is responsible for the mediation of the first social relations of the individual and, thus, is the formative of elements of social identity (Reis, 1984; Gomes, 2013). In the interaction with the wider environment, with parents and peers, children and adolescents have contact with values,

${ }^{1}$ Support: Fundação de Amparo à Pesquisa do Estado de Minas Gerais (APQ-00561-14).

Correspondence address: Marcelo Dalla Vecchia. Universidade Federal de São João del-Rei, campus Dom Bosco. Departamento de Psicologia. Praça Dom Helvécio, 74, São João del-Rei-MG, Brazil. CEP 36.301-160. E-mail: mdvecchia@ufsj.edu.br social norms and community beliefs in which they are inserted from birth (Mendes \& Pessôa, 2013).

The bonds created between the primary forms of socialization may be more fragile, constituting a risk factor for future behavioral problems, or they may be healthy, preventing conflicts with the law or the occurrence of mental suffering in youth and adult life (Schenker \& Minayo, 2003). Although this way of conceiving the relation between primary and secondary sources is somewhat schematic and formal, the family is, above all, a fundamental space for the constitution of subjectivity. In this sense, in order to be better 
understood, it must be considered in its complex interaction with historical, political-economic and socio-cultural determinants, notwithstanding its own internal dynamics (Reis, 1984).

The relationship between the family and the consumption of alcohol and other drugs is ambiguous, and the way it relates to these substances influences the values, way of life and everyday family practices in a different way, constituting a cultural reference that will guide the actions of the individuals (Roehrs, Lenardt, \& Maftum, 2008). In this sense, in general, in the absence of a family member who experiences problems with alcohol and other drugs, there is a differentiation between licit and illicit drugs as regards the way the family accepts certain substances and considers others as a problem. Lopes, Ganassin, Marcon and Decesaro (2015) point out that the use of licit drugs, especially alcohol, is trivialized. The main reason for this would be the ease of access, as well as its legalization and social acceptance, which leads to consent and possible incentive for its consumption.

In this way, the family can be a co-author of both positive developmental opportunities and the emergence of health problems, such as those related to the problematic use of alcohol and other drugs (Alvarez, Gomes, Oliveira, \& Xavier, 2012). In this sense, it is a fundamental element of the social support network to protect children and adolescents from the typical vulnerabilities of this special development situation, but, it may increase their vulnerability (Sapienza \& Pedromônico, 2005).

The recognition of the importance of the family as a source of support in the process of socialization and in the course of life positions it as a central element of care processes. The Ministry of Health Policy for Comprehensive Care for Users of Alcohol and Other Drugs (Atenção Integral a Usuários de Álcool e outras Drogas, Brasil, 2003) emphasizes social support in the treatment of people with problems resulting from alcohol and other drugs use. The construction of a network of flexible and articulated care with existing or potential social support devices aims at generating impacts on risk factors, as well as on facilitating adherence to treatment. The social support network, including the family, contributes to the confrontation of health problems and their consequences (Brusamarell, Guimarães, Labronici, Mazza, \& Maftum, 2011; Canesqui \& Barsaglini, 2012).

The Psychiatric Reform movement proposes changes in theoretical-practical, organizational and technicaladministrative aspects of the traditional psychiatric model. These changes seek to affect the work process in mental health (Abrahão, Azevedo, \& Gomes, 2017, Zgiet, 2013). However, the characteristics of care provision in this field are linked to the historical, sociocultural and political-economic circumstances of each place and region (Maciel, 2012). In Brazil, the Psychiatric Reform, since the 1970s, struggles for the rupture of the mental hospital culture and the centrality of psychiatric knowledge. It denounced the privative medical-assistance paradigm and denounces practices that maintain the segregation and stigmatization of people in mental suffering, as well as point out principles for integral care (Dalla Vecchia \& Martins, 2009). The struggle against the mental hospital proposes new attention models that aim to overcome selective and focused assistance models and anachronistic institutions and producers of social exclusion (Soalheiro, 2012).

The family, in this scenario, is considered an important ally in the health promotion and as a health care place, strengthening participation and popular organization in mental health services. This attitude seeks to promote the autonomy of family care based on solidarity and on its social support networks (Dimenstein, Sales, Galvão, \& Severo, 2010). Prior to the Psychiatric Reform, the family was expected to play a passive role, and its knowledge was disregarded, since the treatment offered by mental health services was based centrally on biomedical practices and social isolation (Rosa, 2005). The Reform sought to redirect the individual to full care in open and community services, preserving and respecting his/her social bonds and citizenship rights, demanding a re-signification of the place of the family in this process (Brasil, 2003).

There is a re-signification of the place of the family by the mental health services, while its configuration has also changed historically. The feminist movement proposes that the role of women should not be restricted to the place of caregiver, questioning the gender division in which the woman is responsible for the house and children while the man is responsible for the financial sustenance (Borsa \& Nunes, 2011). However, women are still centrally involved in health care activities, both in a formal way, according to the professional prescriptions, and through informal care carried out by mothers, wives, sisters-in-law and grandmothers in the home (Rosa, 2005).

In the case of the family member who experiences problems resulting from the use of alcohol and other drugs, the impacts on the person and his/her family lead to the distrust of him/her to handle his/her responsibilities, failing to recognize him/her as contributing to the daily life of the family and their needs, which affects the quality of life of the family group (Lopes, Ganassin, Marcon, \& Decesaro, 2015). Damage can cause feelings of helplessness and frustration. In addition, they may exacerbate existing conflicts that threaten family routine and dynamics (Horta et al., 2016).

Mistaken common-sense beliefs that understand people with problems resulting from the use of alcohol and other drugs as sinners (religious conception), delinquents (criminal conception) or patients (medical conception) create a stigma that affects drug users. The stigma would be a process shaped by historical or social forces, responsible, among other consequences, for moving drug users away from health services (Noto, Ronzani, Silveira, \& Soares, 2013). According to Goffman (2012), moral stigmas correspond to attributes and faults of individual character, being related, for example, to the problematic use of alcohol and other drugs. Discrimination, prejudice and, in particular, stigma, which arise from the social imaginary and fall on the user of drugs, end up being a barrier to the search and continuity of treatment, often 
excluding the user from the right to health care (Ronzani, Silveira, Casela, Andrade, Monteiro, \& Freitas, 2014).

Given this complex and intricate framework, this article aimed to understand the meanings made by people with problems resulting from the use of alcohol and other drugs that are (or have been) in treatment about family participation. Family members have experienced situations of overloading in psychosocial care due to the fragility of social policies to support the family (Delgado, 2014; Reis, Dahl, Barbosa, Teixeira, \& Delgado, 2016). In this sense, recognizing the place of the family in this process and identifying the challenges to their participation in the care of the family member who is experiencing problems due to the use of alcohol and other drugs is relevant for the elaboration and planning of care actions, especially in actions and services developed by the Network of Psychosocial Care (acronym in Portuguese: RAPS).

\section{Method}

\section{Participants}

The research was carried out in an institution similar to a therapeutic community (TC) that, however, differs from the vast majority of these institutions by having a medical clinic in its physical space. It is located in a city in the interior of the state of Minas Gerais and serves people who abuse or depend on psychoactive substances. It has the capacity to accommodate around 35 people simultaneously, also having a technical team that counts with a doctor, psychologist and social worker.

The residential treatment offered by the institution has a total duration of approximately one year and two months, being divided into two stages: hospitalization and post-treatment. The period of hospitalization covers the first two months and refers to the period of intensive care, with treatment activities every day of the week. After discharge from the institution, the post-treatment begins, which lasts one year.

The adopted model presupposes that the treatment counts on the follow-up of family members as a mandatory part of the patient's stay in the period of hospitalization. This monitoring starts immediately after the admission interview, when it is clarified about the treatment, the rules of the institution and, soon, the patient is admitted.

Weekly, lectures take place, which comprise the family program, whose objective is to clarify that, in the perspective of the proposed treatment, the problematic use of alcohol and other drugs is a disease that has repercussions in the family context and in society. During the period of hospitalization, the family is also called for a specific activity with the therapist responsible for the resident. During the posttreatment, there is no mandatory follow-up by the family.

Based on the indication of the therapeutic team, six semi-structured interviews were conducted with people who were already treated or are being treated, one woman and five men, whose age ranged from 32 to 51 years. All interviewees reported having been user of multiple psychoactive substances, alcohol being consumed together with weed, cocaine and/or crack.

\section{Instruments}

The interview is an important technique when one intends to understand how the individuals mean their reality, as well as the logic that governs the relations between the subjects (Duarte, 2004). Since reality is better understood intersubjectively, the semi-structured interview is characterized by allowing an active process of verbal and non-verbal exchanges between the researcher and the interviewee (Fraser \& Gondim, 2004).

A first interview was conducted with the character of 'pilot interview', aiming at the validation of the script of the semi-structured interview that was used. The script, at the end, contemplated the following questions: (1) Why did you seek treatment?; (2) From whom did the initiative start for seeking help?; (3) How did/do your family deal with your problem with alcohol and other drugs?; (4) In the treatment process, how has your family been involved?; (5) How do you perceive / evaluate the presence of your family in your treatment? The use of the interview allows a more accurate description and a better understanding of how the individuals mean, perceive and evaluate the participation of their family in their treatment, also allowing the interviewee to reflect on their own conceptions and beliefs.

\section{Procedure}

Data collection. Based on the indications of potential participants made by the institutional therapeutic team, contacts were made with the purpose of clarifying the objectives and questioning the interest in providing its testimony. Interviews would be conducted alternately with individuals who were successful in treatment (which means, from the perspective of the institution's therapeutic proposal, to be abstinent) and with those who relapsed (that is, returned to recreational use, sporadic, abusive or dependent) after completion of treatment, or who have not been able to fully complete the proposed program.

However, contact with individuals who did not adhere to the proposed treatment proved to be more difficult, and only an interview of these cases was possible. This was possibly because the contact of the researchers was interpreted as a contact of the institution itself, possibly undesired shortly after its withdrawal from treatment because it did not meet the criteria of the institution. The interviews were about 25 minutes long.

Data analysis. The thematic content analysis method was used to analyze the data collected in the interviews (Braun \& Clarke, 2006). First, the transcription of the interviews recorded in audio was carried out. After repeated readings of its content, thematic categories were identified that articulated the most significant aspects of the testimonies, in the light of the objectives set for the research (Bardin, 2015). 


\section{Ethical Considerations}

The research was authorized by the institution and, having met the ethical criteria, was approved for development by the Research Ethics Committee Involving Human Beings - Educational Units of São João del-Rei (Acronym in Portuguese: CEPSJ). After the first contact and after the acceptance of the participants, the interviews were scheduled and information about secrecy and anonymity were passed on, and it was also informed that the refusal to participate in the research could occur at any time. Participants signed a Free and Informed Consent Term (FICT) that also informed about the use of a digital recorder.

\section{Results}

\section{Lack of Family Involvement during Treatment}

Interviewees who had the family involved in all stages of treatment in an active and voluntary manner highlighted in their speeches the importance of this participation. In the excerpts below it is possible to perceive the relevance attributed to the family participation during the treatment, sharing the institutional discourse: "everyone was present in the family program, especially my wife and mother. They supported me. They were inside the situation, understanding, treating themselves and automatically understanding chemical dependence" (Carlos). "It was important. They participated in all groups. In the family program, my wife and mother went to meetings" (Pedro).

In this sense, it is understood the importance of the presence of the family in the care, in a perspective in which this one would no longer be seen as passive, but participant of the treatment. Family involvement as a form of support, strengthening relationships and information acquisition has the potential to make treatment more effective (Schenker \& Minayo, 2003).

It is noted, however, through the highlighted fragments, that it is understood that this participation decreases during the course of the treatment. It was possible to observe that the perception that the family offers support during the hospitalization regime is directly related to this participation in the groups offered by the family program. The decrease in family participation is highlighted in excerpts from the interviews: "After the conclusion [of the hospitalization] they all stopped coming to the group. I'm going alone to the group" (Pedro).

My mother, for a long time, attended Nar-anon and Al-anon until after my hospitalization. After the treatment was completed, she continued attending. But I think for my mother it was getting very exhausting ... Then she ended up dropping out the treatment. Not my wife. Shortly before completing my treatment she had already dropped her treatment, which would also be for the rest of her life (João).
The understanding that family members have an active role in treatment starts since the search of an institutional support until its continuity in treatment. In the interviews, the participation of the family in groups and the following up of the individual is defined as a source of comfort and safety. Some interviewees stress the importance of this participation so that the family can be informed about what does consist the abuse and dependence of alcohol and other drugs.

The families of two of the interviewees stood out because they were, according to their reports, on the margins of treatment, characterized by fragile and conflicted relationships. It is emphasized that social networks are directly linked to the individual's physical and mental health; In this sense, the more diversified and comprehensive the social networks are, the greater will be the psychosocial resources of that individual, therefore, the less vulnerable they will be facing a crisis (Souza, Kantorski, \& Mielke, 2006). In the section highlighted below, Ana emphasizes the family's distancing during the treatment: "I'm not going to the post-treatment anymore. And they also do not care much about what happens to me, with my life ... We are not a united family" (Ana).

In this case, the family is absent throughout the treatment, and according to their report, this distance persists even in the post-treatment:

On Saturday we were getting ready, always waiting for someone. No one was coming. A revolt ... Even here, it was revolt. I thought, "they do not give a shit about people." ... They do not care about us. I even ask myself, "Wow, what family?" (Ana).

The perception of detachment and disregard for her condition make the interviewee not involve the family in matters related to the treatment. However, at another point in the interview, she places the family as a "bridge" to her arrival until the institution where she would be hospitalized, since Ana reports that it was her son and a friend who encouraged her to start treatment at the institution. It reports no more direct participation or other support in the subsequent stages of treatment.

Like Ana, Fábio did not adhere to the treatment proposed by the institution, but in his interview the family presents itself as an important source of material support, despite the fragility in affective support relationships: "as far as possible, if I needed anything, to come to the institution, they helped me. With car, gasoline, motorcycle. . . . When I had to leave, to receive something, they would come and pick me" (Fábio).

Notwithstanding the material support offered, the interviewee justifies the affective distancing in the treatment because he is the first individual in the family to experience problems resulting from the use of alcohol and other drugs. Thus, because they are often frail relationships and restricted family contact, the actions attributed to the family member being treated are permeated by stigmas that disregard the 
subjective suffering experienced due to the problematic pattern of use of psychoactive substances. In these circumstances, the deponents report withdrawing from social life for fear of stigma, suffering or shame.

\section{The Stigmatization and Individualization of the Prob- lematic Use of Alcohol and Other Drugs}

Social marks as stigmas that these individuals carry are present in the social imaginary of both the family and the community in general, and also affect the way the individual perceives himself (Moraes \& Montenegro, 2014). The family of the user ends up receiving a "courtesy stigma" (Goffman, 2012, p. 41), defined by the author as the stigma that falls on individuals who have a direct relation with the stigmatized, who also are not accepted in certain groups due to this relationship.

Stigma and loss of family trust influence the self-concept of the individual being treated. This is evident in interviews when deponents cite stigmatized behaviors such as theirs and attribute pejorative terms to users of alcohol and other drugs. Interviewees, in their entirety, use terms such as "addict" to define their conduct towards drugs and, even in the case of terms and expressions coined by the institution, declare that their use is their sole and exclusive responsibility, making it possible to infer that deals with internalized stigma.

Excessive consumption is understood as a lack of control, and also that the current usage pattern is their own responsibility. In short, drug use as an individual problem is evident in Fábio's speech when asked about how his family understands the use of drugs: "condemns. Do not like. They say it's too much weakness, that I have to be stronger.". Interviewees report that hospitalization itself is seen as weakness, delegating responsibility for care to the individual under treatment. The lack of information about the treatment and problematic use of alcohol and other drugs may also, as in the case of Fábio, move away the person from treatment:

My father said, "What do you want? Do you want to be hospitalized again? You do not have to be hospitalized, you have to have a word, you have to have an opinion." I said, "No, I will not hospitalize myself, I will have an opinion. But the business is not as you think it is, it's not as easy as you think." I'm going to try to get a treatment without getting hospitalized (Fábio).

Other pejorative behaviors are associated with the image of users of alcohol and other drugs, such as "lies" told to family members in order to make use of the substance of preference. In the interviews, it is noticed that the socalled "lies" generate distrust in the family network, and consequently a distancing between family members and the family member who makes harmful use of alcohol and other drugs. At one point in Ana's interview, she mentions "the lies that every addict [sic] speaks and that end up working," indicating that it is a way of acting that is considered ordinary in the interviewee's perspective. Ana's speech also refers to internalized stigma or self-stigma, which is the attribution of socially constructed stigma to oneself (Noto, Ronzani, Silveira, \& Soares, 2013), which may have treatment and psychosocial implications, such as social isolation.

Certain behaviors attributed by professionals and laymen to people with problems resulting from the use of alcohol and other drugs, such as being "liars" or "manipulators", may result both from the imposition of abstinence as the principle, means and aim of the treatment, as well as from the cultural imposition of the so-called "healthy lifestyle" and the existence of different and creative ways of relating to drugs and reducing harm is not allowed (Spink, 2010). In this sense, the "lies" reported by the interviewees may constitute a form of resistance to domestication imposed by certain principles of socially sanctioned treatments (Moraes \& Montenegro, 2014).

\section{Care Focused on the Figure of Women}

It is evidenced by the reports that the care burdens to the people in treatment are linked to the figure of women: the mothers, the wives and the daughters-in-law, as reported in the interviews of Pedro, Carlos and Alex. All interviewees indicate that these women were the most active participants during hospitalization. According to Pedro, "my mother and my wife always went to meetings, they always came, they were always present during my recovery during hospitalization." The same type of participation is mentioned by Carlos: "who came was my mother, my sister-in-law and my wife [pause]. My big brother came once.".

Historically, the woman has occupied the space of caregiver within the family dynamics, being responsible for the support to the other members of the family. More specifically, in regard to care with the familiar drug user, the caregiver often experiences a process of becoming ill and anguished (Lopes, Nóbrega-Therrian, Araújo, Gomes, \& Cavalcante, 2015).

Thus, because care is focused on the woman's figure, interviewees end up justifying their treatment, in part, to preserve the well-being of wives, mothers and daughters. It is what is understood as an obligation or commitment that they have of reciprocity with the care they provide, as well as to seek to rescue affective bonds and previous links to problematic use of alcohol and other drugs:

I did the recovery for myself, but when I saw the look of my mother entering the institution and see that I was clean, and she imagining "thank God he'll never use drugs again", it gave me pleasure to continue in recovery. It turned out that I did more for myself, but automatically I gratified her more than myself. Not that I'm dissatisfied with my recovery, on the contrary, but I see that she, my wife, and my daughters are happier than me for not using drugs (Carlos). 
It is also worth noting, as far as the centrality of women in the care process is concerned, that Ana's case is emblematic. Her son participates in the process of seeking help, however, does not get involved in the activities of the family program and the treatment as a whole. She mentions that the person most involved in her treatment is a friend, since her closest relatives are men: "Best friend indeed, she even cried. She saw me cry, she cried too. And she said like this "Sonia, you're such a nice person, do not do it with your life. That's right, the best thing you're doing is seeking help. That's right'.

\section{Discussion}

The TC in which the research was performed requires the family to attend to specific activities during the period of hospitalization, in addition to suggesting participation in mutual aid groups outside the institution. Despite this, it was possible to identify in the interviews a progressive distancing of the families during the treatment, even when there is an intense involvement in the search for help to the family member. This distancing was often justified by other family commitments, such as the work routine, making it impossible to attend meetings.

Also in this sense, it was possible to identify the predominance of female relatives in the treatment support, such as wife, daughter, mother and sister-in-law. Mothers and wives remained in the treatment during the stage where the family presence was obligatory, however, it was not possible to perceive this participation during the posttreatment, since it is an optional involvement. This suggests a questioning about how the family is conceived by the treatment program offered by the institution: it is effectively mobilizing the family as the protagonist of the treatment, or a partner in the sense of sustaining the idea that problematic use of alcohol and other drugs is a disease with expressions at home? Future research involving institutional actors could clarify this issue.

It is worth noting that, for the interviewees, the presence of the family is marked in two central and distinct moments: as context for the beginning of drug use, and in the identification of resources and search for treatment. In this sense, most interviewees report that the initial experimentation of drugs, licit and illicit, relates in some way to the family context. In all the interviews the family appears as one of the reasons for the beginning of the treatment, because the family members are the ones who are pressing for the treatment, accompanying the search for help or the constraints generated in family life due to problematic drug use.

The research evidenced the importance of articulating family relationships to the care of the person who lives problems resulting from the use of drugs, since the family constitutes a place of protection and assistance, but also it is where, commonly, occurs the first experimentations of tobacco, alcohol and other drugs. In fact, it is still necessary for the treatment to intervene in the reduction of the stigmas associated to the user by the family itself, demystifying the idea that this is an individual issue. In this sense, the support of the family constitutes one of the elements of a network of relations of the individual, whereas their health care must occur in interface with other contextual supports, as friends, neighbors, co-workers, etc.

A relevant limitation of the study was the fact that interviews with family and institutional actors were not conducted, which could have increased the understanding of social support, based on the experiences of the families mentioned in the interviews. It is suggested that in future investigations on this subject, reports from other involved segments such as the family and institutional providers are included. As regards, specifically, the implications for the professional practice of the psychologist, the research made it possible to show that the needs for orientation, listening and support to family members need to be properly addressed during the treatment in order to favor the involvement on the treatment of people with problems resulting from the use of alcohol and other drugs.

\section{References}

Abrahão, A. L., Azevedo, F. F. M. \& Gomes, M. P. C. (2017). A produção do conhecimento em saúde mental e o processo de trabalho no Centro de Atenção Psicossocial [Production of knowledge in mental health and the work process ate the psychosocial care center]. Trabalho, Educação e Saúde, 15(1), 55-71. doi:10.1590/1981-7746-sol00041

Alvarez, S. Q., Gomes G. C., Oliveira A. M. N, \& Xavier D. M. (2012). Grupo de apoio/suporte como estratégia de cuidado: Importância para familiares de usuários de drogas [Support group as a strategy of care: the importance for relatives of drug users]. Revista Gaúcha de Enfermagem, 33(2), 102-108. doi:10.1590/S1983-14472012000200015

Bardin, L. (2015). Análise de Conteúdo [Content analysis]. Lisboa: Edições 70.

Borsa, J. C., \& Nunes, M. L. T. (2011). Aspectos psicossociais da parentalidade: $O$ papel de homens e mulheres na família nuclear [Psychosocial aspects of parenting: Men and women's role in nuclear families]. Psicologia Argumento, 29(64), 31-39.

Burns, J. E. (2002). O caminho dos doze passos: o tratamento de dependência de álcool e outras drogas [The path of the twelve steps: the treatment of dependence on alcohol and other drugs]. São Paulo: Loyola.

Brasil. Ministério da Saúde. Secretaria de Políticas de Saúde. Departamento de Atenção Básica. (2003). A Política do Ministério da Saúde para a Atenção Integral a Usuários de Álcool e outras Drogas [Politics of the Ministry of Health for the Comprehensive Care of Users of Alcohol and Other Drugs]. Brasília: Autor.

Braun, V., \& Clarke, V. (2006). Using thematic analysis in psychology. Qualitative research in psychology, 3(2), 77-101. doi:10.1191/1478088706qp063oa 
Brusamarello, T., Guimarães A. N., Labronici L. M., Mazza V. A., \& Maftum, M. A. (2011) Redes sociais de apoio de pessoas com transtornos mentais e familiares [Social support networks for people with familiar and mental disorders]. Texto \& Contexto Enfermagem, 20(1), 33-40. doi:10.1590/S0104-07072011000100004

Canesqui, A. M., \& Barsaglini R. A. (2012). Apoio social e saúde: pontos de vista das ciências sociais e humanas [Social support and health: standpoints from the social and human sciences]. Ciência \& Saúde Coletiva, 17(5), 1103-1114. doi:10.1590/S1413-81232012000500002

Dalla Vecchia, M., \& Martins, S. T. (2009). Desinstitucionalização dos cuidados a pessoas com transtornos mentais na atenção básica: aportes para a implementação de ações [Deinstitutionalization of care for people with mental disorders in basic care: contributions to the implementation of actions]. Interface: Comunicação, Saúde, Educação, 13(28), 151-164. doi:10.1590/S1414-32832009000100013

Delgado, P. G. (2014). Sobrecarga do cuidado, solidariedade e estratégia de lida na experiência de familiares de Centros de Atenção Psicossocial [Family burden, support groups and coping style among family members of patients in Psychosocial Care Centers]. Physis: Revista de Saúde Coletiva, 24(4), 1103-1126. doi:10.1590/S0103-73312014000400007

Dimenstein M., Sales A. L., Galvão E., \& Severo A. K. (2010). Estratégia da Atenção Psicossocial e participação da família no cuidado em saúde mental [The Psychosocial Care Strategy and family participation in mental health care]. Physis: Revista de Saúde Coletiva, 20(4), 1209-1226. doi:10.1590/S0103-73312010000400008

Duarte, R. (2004). Entrevistas em pesquisa qualitativas [Interviews in qualitative research]. Educar, 24(1), 213-225. doi:10.1590/0104-4060.357

Fraser, M. T. D., \& Gondim, S. M. G. (2004). Da fala do outro ao texto negociado: discussões sobre a entrevista na pesquisa qualitativa [From the speech of the other to the negotiated text: discussions about the interview in the qualitative research]. Paidéia, 14(28), 139-152. doi:10.1590/S0103-863X2004000200004

Goffman, E. (2012). Estigma: Notas sobre a manipulação da identidade deteriorada [Stigma: notes on the management of spoiled identity]. Rio de Janeiro: LTC.

Gomes, J. V. (2013). Socialização primária: Tarefa familiar [Primary socializing: a family task]. Cadernos de Pesquisa, 91, 54-61.

Horta, A. L. M., Daspett, C., Egito, J. H. T., \& Macedo, R. M. S. (2016). Vivência e estratégias de enfrentamento de familiares de dependentes [Experience and coping strategies in relatives of addicts]. Revista Brasileira de Enfermagem, 69(6), 1024-1030. doi:10.1590/0034-7167-2015-0044
Lopes, A. P. A. T., Ganassin, G. S., Marcon, S. S., \& Decesaro, M. D. N. (2015). Abuso de bebida alcoólica e sua relação no contexto familiar [Alcoholic beverage abuse and its relationship in the family context]. Estudos de Psicologia (Natal), 20(1), 22-30. doi:10.5935/1678-4669.20150004

Lopes, R. E., Nóbrega-Therrian, S. M., Araújo, P. A., Gomes, B. V. \& Cavalcante, M. M. B. (2015). Quando o conviver desvela: assistência de saúde mental às mulheres com familiares usuários de droga [When living together unveils: mental health care for women with drug users in the family]. Sanare, 14(1), 22-26.

Maciel, S. C. (2012). Reforma psiquiátrica no Brasil: algumas reflexões [Psychiatric reform in Brazil: a few reflections]. Cadernos Brasileiros de Saúde Mental, 4(8), 73-82.

Mendes, D. M. L. F., \& Pessôa, L. F. (2013). Comunicação afetiva nos cuidados parentais [Affective communication in parental care]. Psicologia em Estudo, 18(1), 15-25. doi:10.1590/S1413-73722013000100003

Moraes, M. \& Montenegro, M. (2014). Autoridade e imposição de limites: atributos necessários na atenção à saúde de pessoas que consomem drogas? [Authority and imposing limits: Are necessary attributes for healthcare of people who use drugs?] Nova Perspectiva Sistêmica, 48, 57-63.

Reis, J. R. T. (1984). Família, emoção e ideologia [Family, emotion and ideology]. In S. T. M. Lane \& W. Codo (Orgs.), Psicologia social: $O$ homem em movimento [Social psychology: the man in movement] (pp. 99-124). São Paulo: Brasiliense.

Reis, T. L., Dahl, C. M., Barbosa, S. M., Teixeira, M. R., \& Delgado, P. G. G. (2016). Sobrecarga e participação de familiares no cuidado de usuários de Centros de Atenção Psicossocial [Burden and participation of family in the care of Psychosocial Care Centers users]. Saúde em Debate, 40(109), 70-85. doi:10.1590/0103-1104201610906

Roehrs, H., Lenardt, H., \& M. Maftum, M. A. (2008). Práticas culturais familiares e o uso de drogas psicoativas pelos adolescentes: Reflexão teórica [Family culture practices and psychoactive drug abuse by adolescents: Theoretical reflection]. Escola Anna Nery Revista de Enfermagem, 12(2), 353-357. doi:10.1590/S1414-81452008000200024

Ronzani, T. M., Noto, A. R., \& Silveira, P. S. (2014). Reduzindo o estigma entre usuários de drogas. Guia para profissionais e gestores [Reducing stigma among drug users. Guide for professionals and managers]. Juiz de Fora: Editora UFJF.

Ronzani, T. M. (Ed.). (2013). Ações integradas sobre drogas: Prevenção, abordagens e políticas públicas [Integrated actions on drugs: Prevention, approaches and public policies]. Juiz de Fora: Editora UFSJ. 
Rosa, L. C. S. (2005). A inclusão da família nos projetos terapêuticos dos serviços de saúde mental [Inclusion of the family in therapeutical projects of mental health services]. Psicologia em Revista, 11(18), 205-18.

Sapienza, G., \& Pedromônico, M. R. M. (2005). Risco, proteção e resiliência no desenvolvimento da criança e do adolescente [Risk, protection and resilience in the development of children and adolescents]. Psicologia em Estudo, 10(2), 209-216. doi:10.1590/S1413-73722005000200007

Schenker, M., \& Minayo, M. C. S. (2003). A implicação da família no uso abusivo de drogas: Uma revisão crítica [The family implication on the drug abusive use: a critical review]. Ciência \& Saúde Coletiva, 8(1), 299-306. doi:10.1590/S1413-81232003000100022

Silveira P. S., \& Silva, E. A. (2013). Família, sociedade e uso de drogas: Prevenção, inclusão social e tratamento familiar. [Family, Society and Drug Use: Prevention, Social Inclusion and Family Treatment] In T. Ronzani (Org.), Ações integradas sobre drogas: Prevenção, abordagens e politicas públicas [Integrated actions on drugs: prevention, approaches and public policies]. Juiz de Fora: Ed.UFJF.

Soalheiro, N. I. (2012). A política e empoderamento de usuários e familiares no contexto brasileiro do movimento pela reforma psiquiátrica [Politics and empowerment of users and family in the brazilian context for psychiatric reform]. Cadernos Brasileiros de Saúde Mental, 4(8), 30-44.

Souza, J. D., Kantorski, L. P., \& Mielke, F. B. (2006). Vínculos e redes sociais de indivíduos dependentes de substâncias psicoativas sob tratamento em CAPS AD [Bonds and social networks among individuals dependent on psychoactive substances under treatment at a CAPS AD]. SMAD: Revista Eletrônica Saúde Mental Álcool e Drogas, 2(1), 47-62. doi:10.11606/issn.1806-6976.v2i1p01-17

Spink, M. J. (2010). Ser fumante em um mundo antitabaco: reflexões sobre riscos e exclusão social [Smokers in an Anti-tobacco World: Reflections on risks and social exclusion]. Saúde e Sociedade, 19(3), 481-496. doi:10.1590/S0104-12902010000300002

Zgiet, J. (2013). Reforma psiquiátrica e os trabalhadores da saúde mental: A quem interessa mudar? [Psychiatric care reform and mental health workers: Change in whose interest?] Saúde em Debate, 37(97), 313-323.

Lais Ramos Sanches holds a M.Sc. from the Universidade Federal de São João del-Rei.

Tassiana Gonçalves Constantino dos Santos is a M.Sc. candidate from the Universidade Federal de São João del-Rei.
Thaisa Borges Gomes is a M. Sc. candidate from the Universidade Federal de São João del-Rei.

Marcelo Dallla Vecchia is a Professor of the Universidade Federal de São João del-Rei.

Received: Mar. 13, 2017

1st Revision: Apr. 26, 2017

2nd Revision: Dec. 19, 2017

Approved: Jan. 29, 2018

How to cite this article:

Sanches, L. R., Santos, T. G. C., Gomes, T. B., \& Dalla Vecchia, M. (2018). Meanings of family support in the treatment of drug dependence. Paidéia (Ribeirão Preto), 28, e2824. doi:http://dx.doi.org/10.1590/1982-4327e2824 